\title{
Pengaruh Biaya Operasional dan Perputaran Persediaan terhadap Laba Bersih
}

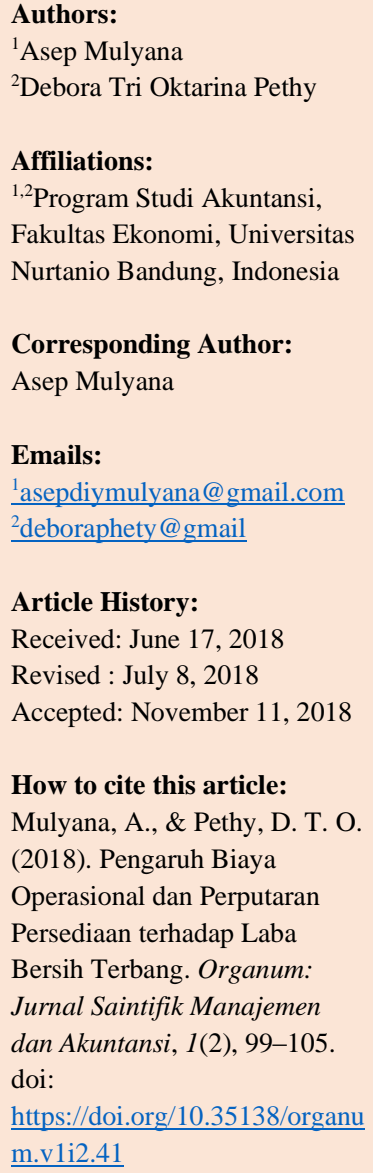

Article History:

Received: June 17, 2018

Revised : July 8, 2018

Accepted: November 11, 2018

How to cite this article: Mulyana, A., \& Pethy, D. T. O. (2018). Pengaruh Biaya Operasional dan Perputaran Persediaan terhadap Laba Bersih Terbang. Organum: Jurnal Saintifik Manajemen dan Akuntansi, 1(2), 99-105. doi:

https://doi.org/10.35138/organu m.v1i2.41

\section{Journal Homepage:} ejournal.winayamukti.ac.id/ind ex.php/Organum

Copyright:

(C) 2018. Published by Organum: Jurnal Saintifik Manajemen dan Akuntansi. Faculty of Economics and Business. Winaya Mukti University.

\begin{abstract}
This study aims to determine how much influence the operational costs and inventory turnover on net income at PT Ultrajaya Milk Industry \& Trading Company Tbk., both partially and simultaneously. The research method used is descriptive with a quantitative approach, while the statistical method used is multiple linear regression by first testing the classical assumptions using the SPSS V.25 program. The results of this study indicated that the data tested were standard with the results of the normality test using the Kolmogorov Smirnov $(K-S)$ table and scatterplot, correlation coefficient tests. The data used in this study was taken from the company's annual financial report of PT Ultrajaya Milk Industry \& Trading Company Tbk., for seven years, namely the period 2011-2017. It showed a very strong relationship, and partially operational costs affected net income, while inventory turnover did not affect net income. Also, simultaneously, operational costs and inventory turnover affected net income.
\end{abstract}

Keywords: Operating costs; inventory turnover; net profit.

Abstrak. Penelitian ini bertujuan untuk mengetahui seberapa besar pengaruh biaya operasional dan perputaran persediaan terhadap laba bersih pada PT Ultrajaya Milk Industry \& Trading Company Tbk., baik secara parsial dan simultan. Metode penelitian yang digunakan yaitu deskriptif dengan pendekatan kuantitatif. Sedangkan metode statistik yang digunakan adalah regresi linier berganda dengan melakukan uji asumsi klasik terlebih dahulu menggunakan program SPSS V.25. Hasil penelitian ini menunjukkan bahwa data yang diuji normal dengan hasil uji normalitas yang menggunakan tabel Kolmogorov Smirnov (K-S) dan scatterplot, uji koefisien korelasi. Data yang digunakan dalam penelitian ini diambil dari laporan keuangan tahunan perusahaan PT Ultrajaya Milk Industry \& Trading Company Tbk., selama kurun waktu tujuh tahun yaitu periode 2011-2017. Menunjukkan hubungan yang sangat kuat dan secara parsial biaya operasional berpengaruh terhadap laba bersih, sedangkan untuk perputaran persediaan tidak berpengaruh terhadap laba bersih. Selain itu, secara simultan biaya operasional dan perputaran persediaan berpengaruh terhadap laba bersih.

Kata kunci: Biaya operasional; perputaran persediaan; laba bersih.

\section{Pendahuluan}

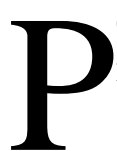
esatnya perkembangan infrastruktur dan semakin mudahnya para pengusaha dalam menembus sekat antarnegara menjadikan dunia usaha semakin kompetitif. Ketatnya dalam persaingan usaha menuntut perusahaan agar mampu menjaga reputasi dan bertahan dalam persaingan di 
dunia industri manufaktur. Namun, dalam bersaing tentu dibutuhkan strategi maupun upaya untuk meningkatkan kualitas dan kuantitas industri dengan skala besar yang disesuaikan dengan tatanan atau aturan perusahaan sesuai prosedur yang berlaku dari pihak manajemen.

Keuntungan dari hasil usaha industri menjadi salah satu patokan perusahaan dalam melakukan kegiatan perusahaan. Dengan adanya capaian atau patokan atau capaian keuntungan yang besar, maka akan membuat perusahaan berkembang bahkan membuka peluang usaha industri yang baru. Kebutuhan yang diperlukan dalam membuka usaha industri yang baru yaitu kebutuhan akan SDM atau tenaga ahli, sehingga dengan adanya tenaga ahli ini memberikan peluang usaha industri yang mampu bersaing dengan industriindustri lain. Kreativitas dan inovasi dari tenaga ahli tersebut dalam berkarya menjadi tolok ukur keberlangsungnya perusahaan untuk jangka waktu yang lama. Oleh karena itu, dengan adanya inovasi dan kreativitas akan menjadikan suatu persaingan yang sangat menarik dan dalam skala nasional atau bahkan membawa perkembangan usaha menuju skala internasional yang sangat kompleks.

Fenomena terkait dengan laba bersih yang meningkat dari tahun 2011 sampai 2017 yang dikutip dari Laporan Tinjauan Keuangan PT Ultrajaya Milk Industri \& Trading Company Tbk., 2015 mengalami kenaikan diindikasi karena penjualan bersih untuk tahun fiskal (FY) 2015 mengalami peningkatan.

Dalam dunia industri, proses operasional perusahaan tidak lepas dari kegiatan operasional yang memerlukan pengolahan bahan baku menjadi barang jadi. Bahan baku menjadi salah satu kendala dalam proses produksi jika bahan baku didatangkan dari luar negara yang diproduksi atau import. Kendala yang sering terjadi yaitu tidak ada kontrak harga yang ditentukan oleh kedua belah pihak, sehingga kontrak tersebut hanya mengacu pada kurs mata uang internasional yang menjadi patokan transaksi dalam jual beli. Tentunya selain bahan baku masih banyak aspek yang harus dipahami dan diteliti dari berbagai macam aspek agar proses produksi bisa berjalan lancar.

Dalam menjalankan aktivitasnya suatu perusahaan yang bergerak dalam bidang industri akan mengeluarkan dua jenis biaya, yang dikategorikan menjadi biaya bahan baku dan biaya operasional. Biaya bahan baku merupakan seluruh persediaan, yang meliputi persediaan bahan baku, persediaan barang setengah jadi, dan persediaan barang jadi. Sedangkan, biaya lain yang dibutuhkan untuk kelancaran penjualan dan pemasaran administratif disebut dengan biaya operasional. Fenomena biaya operasional yang terjadi pada PT Ultrajaya Milk Industri selama periode 2011-2017 mengalami perubahan yang fluktuatif.

Salah satu faktor yang dapat berpengaruh terhadap laba bersih adalah perputaran persediaan. Perputaran persediaan merupakan rasio yang digunakan untuk mengukur berapa kali dana yang ditanam dalam persediaan ini berputar dalam satu periode. Rendahnya perputaran berarti menunjukkan banyak kapital atau modal kerja yang berhenti di barang persediaan tersebut dan tidak dapat dimanfaatkan. Jika kita bisa menjual barang persediaan tersebut dengan cepat, maka hal ini akan memperbaiki keuntungan perusahaan. Perputaran persediaan pada PT Ultrajaya Milk Industri selama periode 2011-2017 menunjukkan tidak terjadi perubahan yang signifikan pada periode tahun 2011 sampai 2017.

\section{Kajian Literatur}

Menurut Simamora (2013:46), laba bersih adalah berasal dari transaksi pendapatan, beban, keuntungan, dan kerugian. Laba bersih dihasilkan dari selisih antara sumber daya masuk (pendapatan dan keuntungan) dengan sumber daya keluar (beban dan kerugian) selama periode waktu tertentu. Sejalan 
dengan pendapat tersebut Kasmir (2014:303) mengatakan bahwa pengertian laba bersih (net profit) merupakan laba yang telah dikurangi biaya-biaya yang merupakan beban perusahaan dalam suatu periode tertentu termasuk pajak. Dari definisi tersebut dapat disimpulkan bahwa laba bersih merupakan keuntungan yang didapatkan perusahaan setelah dilakukannya pemotongan dana yang digunakan untuk operasional perusahaan.

Setiap perusahaan pastinya akan mengeluarkan biaya untuk operasional perusahaan. Biaya dalam perusahan merupakan pengorbanan untuk mendapatkan nilai atau manfaat di masa yang akan datang. Menurut Siregar (2013:23) biaya adalah pengorbanan sumber ekonomi untuk memperoleh barang atau jasa yang diharapkan memberi manfaat sekarang atau masa yang akan datang. Sedangkan menurut Dunia dan Wasilah (2012:22) biaya adalah pengeluaran pengeluaran atau nilai pengorbanan untuk memperoleh barang atau jasa yang berguna untuk masa yang akan datang, atau mempunyai manfaat melebihi satu periode akuntansi. Sejalan dengan pendapat tersebut Murhadi (2013:37) mengemukakan bahwa biaya operasi (operating expense) merupakan biaya yang terkait dengan operasional perusahaan yang meliput biaya penjualan dan administrasi (selling and administrative expense), biaya iklan (advertising expense), biaya penyusutan (depreciation and amortization expense), serta perbaikan dan pemeliharaan (repairs and maintenance expense). Berdasarkan definisi tersebut dapat disimpulkan bahwa biaya operasional dalam perusahaan merupakan pengeluaran nilai dalam perusahaan untuk kegiatan operasional perusahaan yang di dalamnya memiliki nilai lebih dan manfaat di masa yang akan datang. Sehingga biaya yang digunakan perusahaan akan menjadi perputaran dalam operasional perusahaan itu sendiri.

Perputaran persediaan (inventory turnover) mengukur hubungan antara harga pokok penjualan dengan jumlah persediaan yang dimiliki selama periode berjalan. Perputaran persediaan menurut Kasmir (2014:180) perputaran persediaan merupakan rasio yang digunakan untuk mengukur berapa kali dana yang ditanam dalam persediaan (inventory) ini berputar dalam suatu periode. Sedangkan menurut Raharjaputra (2009:139) menyatakan bahwa semakin tinggi tingkat perputaran persediaan, kemungkinan semakin besar perusahaan akan memperoleh keuntungan, begitu pula sebaliknya, jika tingkat perputaran persediaannya rendah maka kemungkinan semakin kecil perusahaan akan memperoleh keuntungan.

Syamsuddin

(2011:47-48) menambahkan untuk menghitung perputaran persediaan dan menghitung umur rata-rata persediaan adalah Inventory Turnover $=$ Cost of goods sold / average inventory. Dengan umur rata-rata persediaan dimaksudkan untuk mengetahui rata-rata persediaan berada di dalam perusahaan dalam hitungan hari.

Pada hakikatnya laba bersih dan biaya operasional memiliki hubungan yang tidak dapat dipisahkan dalam perusahaan. Menurut Jusuf (2008:35) mengatakan bahwa tujuan dari perusahaan adalah mendapatkan keuntungan yang sangat besar sesuai tujuan perusahaan tersebut. Meskipun persaingan bisnis sangat kompetitif tetapi pendapatan harus melebihi biaya yang di keluarkan oleh perusahaan. Perusahaan dituntut untuk menghitung dan menekan biaya operasional secara efisien dan efektif tanpa mengurangi kualitas produksi. Kesimpulannya adalah pengorbanan perusahaan berkaitan dengan biaya operasional selama produksi yang tujuan utamanya adalah menghasilkan keuntungan atau laba yang diharapkan. Teori ini sejalan dengan hasil penelitian yang telah dilakukan oleh Prasetyo (2017) yang menyatakan bahwa laba bersih dipengaruhi oleh biaya operasional dengan hubungan yang negatif. Namun, 
penelitian yang dilakukan oleh Zandra (2016) menunjukkan bahwa secara parsial variabel biaya operasional (X1) tidak berpengaruh terhadap profitabilitas $(\mathrm{Y})$.

Hubungan laba bersih dengan perputaran persediaan menurut Sartono (2008:444) yaitu bahwa perputaran pesediaan dalam operasional perusahaan sangat penting terutama dalam hal produksi. Apabila persediaan tidak memadai maka akan berakibat kedalam proses produksi terhambat yaitu ada penundaan dalam hal ini adalah bahan baku yang tidak bisa mencukupi kegiatan produksi. Sebaliknya persediaan yang meningkat tajam maka akan berakibat persediaan menumpuk yang mengakibatkan perputaran persediaan tidak sehat sehingga akan mengakibatkan penurunan laba bersih. Hubungan ini ditunjukan dengan penelitian yang dilakukan oleh Prasetyo (2017) yang menyatakan laba dipengaruhi oleh perputaran persediaan dengan hubungan yang positif. Sedangkan, hubungan sebaliknya ditunjukkan pada penelitian Zandra (2016) menunjukkan bahwa secara parsial variabel perputaran persediaan (X2) tidak berpengaruh terhadap profitabilitas (Y).

\section{Metode Penelitian}

Metodologi penelitian yang digunakan dalam penelitian ini yaitu metode penelitian kuantitatif dengan menggunakan pendekatan deskriptif. Menurut Sugiyono (2015:13), metode penelitian kuantitatif dapat diartikan sebagai metode penelitian yang berlandaskan pada filsafat positivisme, digunakan untuk meneliti pada populasi atau sampel tertentu, teknik pengambilan sampel pada umumnya dilakukan secara random, pengumpulan data menggunakan instrumen penelitian, analisis data bersifat kuantitatif/statistik dengan tujuan untuk menguji hipotesis yang telah di tetapkan. Dalam penelitian ini, peneliti mencoba mendeskripsikan data sekunder yaitu laporan keuangan yang memuat biaya opersional, perputaran persediaan, dan laba bersih pada PT Ultrajaya Milk Industri pada periode 2011-201.

Menurut Sugiyono (2015:38), variabel adalah suatu atribut atau sifat atau nilai dari orang, obyek atau kegiatan yang mempunyai variasi tertentu yang ditetapkan oleh penelitian untuk dipelajari dan kemudian ditarik kesimpulannya. Variabel yang digunakan oleh peneliti baik variabel independen maupun variabel dependen menggunakan skala rasio. Variabel independen dalam penelitian ini yaitu biaya operasional (X1) dan perputaran persediaan (X2). Sedangkan variabel dependen dalam penelitian ini yaitu laba bersih (Y).

Untuk memperoleh hasil yang lebih akurat pada analisis regresi berganda maka dilakukan pengujian asumsi klasik agar hasil yang diperoleh merupakan persamaan regresi yang memiliki sifat Best Linier Unbiased Estimator (BLUE). Beberapa asumsi klasik regresi yang harus dipenuhi terlebih dahulu sebelum menggunakan analisis regresi berganda (Multiple Linear Regression) sebagai alat untuk menganalisis pengaruh variabelvariabel yang diteliti. Terdapat empat jenis pengujian pada uji asumsi klasik ini, diantaranya uji normalitas, uji multikolinearitas, heteroskedastisitas, dan autokorelasi.

Ghozali (2016) menjelaskan keempat pengujian tersebut: 1) Uji normalitas bertujuan untuk menguji apakah dalam model regresi, variabel pengganggu atau residual memiliki distribusi normal. Uji ini harus terpenuhi mengingat uji $t$ dan uji $F$ mengasumsikan bahwa nilai residual mengikuti distribusi normal. Uji normalitas dapat menggunakan Kolmogorov-Smirnov Test. Data residual dikatakan terdistribusi normal apabila nilai sig. > 0,05. 2) Uji multikolinearitas bertujuan untuk menguji apakah dalam model regresi ditemukan adanya korelasi antar variabel bebas (independent). Model regresi yang baik 
seharusnya tidak terjadi korelasi di antara variabel independen.

Heteroskedastisitas tidak terjadi jika tidak ada pola yang jelas (bergelombang, melebar kemudian menyempit) pada gambar scatterplots, serta titik-titik menyebar di atas dan dibawah angka 0 pada sumbu Y. 4) Tidak ada gejala autokorelasi, jika nilai Durbin Waston terletak antara du sampai dengan (4-du).

Lebih lanjut, Sugiyono (2015:184) menyatakan analisis koefisiensi korelasi berganda (R) digunakan untuk menerapkan kekuatan dan arah hubungan antar variabel independen dengan variabel dependen. Penulis menggunakan analisis korelasi berganda untuk mengukur kekuatan asosiasi (hubungan) antara variabel independen dan variabel dependen. Sedangkan Ghozali (2016:97) terkait koefisien Determinasi $\left(\mathrm{R}^{2}\right)$ merupakan proposisi variabilitas dalam suatu data yang dihitung berdasarkan pada model statistik. Tujuan analisis ini adalah untuk menghitung besarnya pengaruh variabel independen terhadap variabel dependen. Jika nilai $\mathrm{R}^{2}$ semakin tinggi maka semakin besar proporsi dari total variasi variabel dependen yang dapat dijelaskan oleh variabel independen. Maka jika $\mathrm{R}^{2}=1$ memiliki arti bahwa model yang sesuai dengan semua variabelitas dalam variabel $\mathrm{Y}$ dan jika $\mathrm{R}^{2}$ $=0$ maka mengandung arti bahwa tidak ada hubungan antara variabel $\mathrm{X}$ dengan variabel Y.

Selain menggunakan metode statistik, peneliti juga membandingkan dengan hasil penelitian sebelumnya sehingga akan dihasilkan keakuratan data dan pengambilan kesimpulan yang tepat dalam hasil penelitian ini.

\section{Hasil dan Pembahasan}

Berdasarkan hasil output SPSS V.25, dapat diketahui bahwa biaya operasional paling tinggi pada periode tersebut terjadi di tahun 2015 yaitu sebesar Rp 3.166.159.687.192 dan biaya operasional terendah terjadi di tahun 2011 yaitu Rp 1.468.780.189.453 dengan nilai rata-rata $R p$ 2.045.981.776.003.

Perputaran persediaan paling tinggi terjadi di tahun 2013 yaitu 5,6 kali, sedangkan perputaran persediaan paling rendah terjadi pada tahun 2016 yaitu sebanyak 4 kali. Nilai rata-rata untuk perputaran persediaan yaitu sebanyak 4,6 kali.

Laba bersih paling tinggi pada periode tersebut dihasilkan pada tahun 2015 yaitu sebesar Rp 2.112.339.699.407 dan laba bersih paling rendah terjadi pada tahun 2011 yaitu $\mathrm{Rp}$ 1.069.353.657.782 dengan nilai rata-rata $\mathrm{Rp}$ 1.545.826.112.073.

\section{Pengaruh Biaya Operasional terhadap Laba Bersih}

Hasil pengujian hipotesis yaitu menolak Ho yang artinya biaya operasional berpengaruh terhadap laba bersih. Pengaruh biaya operasional terhadap laba bersih yaitu sebesar $82,08 \%$ dan gapnya $17,92 \%$ dipengaruhi oleh variabel-variabel lain yang tidak diteliti dalam penelitian ini seperti biaya produksi, modal, hutang, pendapatan, dan lain-lain. Hasil pengujian korelasi masuk dalam interval sangat kuat dan bersifat positif, artinya jika biaya operasional mengalami peningkatan maka laba bersih yang diperoleh perusahaan akan mengalami kenaikan. Penelitian ini tidak sesuai dengan teori menurut Jusuf (2008:35) yaitu bila perusahaan dapat menekan biaya operasional, maka perusahaan akan dapat meningkatkan laba bersih. Demikian juga sebaliknya, bila terjadi pemborosan biaya (seperti pemakaian alat kantor yang berlebihan) akan mengakibatkan menurunnya laba bersih (net profit). Jadi besarnya biaya operasional memengaruhi laba bersih. Penelitian ini telah menjawab fenomena yang telah dikemukakan sebelumnya yaitu pada perusahaan PT Ultrajaya Milk Industry \& Trading Company Tbk., yang mengalami kenaikan laba bersih pada tahun 2015. Namun, dari sisi biaya 
operasional pada tahun 2015 mengalami kenaikan. Kenaikan biaya operasional PT Ultrajaya Milk Industry \& Trading Company Tbk., tersebut diikuti oleh peningkatan laba bersih. Keadaan tersebut dikarenakan perusahaan mengalami kenaikan dalam penjualan produknya. Dengan hasil ini menunjukkan bahwa biaya operasional memengaruhi laba bersih. Hasil penelitian ini sejalan dengan penelitian yang dilakukan oleh Prasetyo (2017) namun bertentangan dengan penelitian yang dilakukan oleh Zandra (2016).

\section{Pengaruh Perputaran Persediaan terhadap Laba Bersih}

Hasil pengujian hipotesis yaitu Ho diterima yang artinya perputaran persediaan tidak berpengaruh terhadap laba bersih. Pengaruh perputaran persediaan terhadap laba bersih yaitu sebesar $0,578 \%$ dan gapnya 99,422\% dipengaruhi oleh variabel-variabel lain yang tidak diteliti dalam penelitian ini seperti penjualan, perputaran piutang, perputaran modal kerja, biaya bunga, beban pajak, dan lain-lain.

Hasil pengujian korelasi masuk dalam interval sangat rendah dan bersifat positif, artinya jika perputaran persediaan mengalami peningkatan maka laba bersih yang diperoleh perusahaan akan mengalami peningkatan juga. Penelitian ini sesuai dengan teori menurut Sartono (2008:444), yaitu apabila pesediaan terlalu kecil maka kegiatan operasi besar kemungkinannya mengalami penundaan, atau perusahaan beroprasi pada kapasitas yang kecil. Sebaliknya apabila persediaan terlalu besar maka akan mengakibatkan perputaran persediaan yang rendah sehingga keuntungan/laba perusahaan menurun.

Jadi besarnya perputaran persediaan tidak memengaruhi laba bersih. Hasil ini sejalan dengan penelitian yang dilakukan oleh Zandra (2016), namun bertentangan dengan hasil penelitian Prasetyo (2017). Penelitian ini telah menjawab fenomena yang telah dikemukakan sebelumnya yaitu laba bersih pada perusahaan PT Ultrajaya milk industry \& trading company Tbk., pada tahun 2014 ke 2015 yang mengalami kenaikan laba bersih. Sementara berdasarkan perhitungan, perputaran persediaan yang dicapai perusahaan selama 2 (dua) tahun tersebut stabil (tidak naik atau pun tidak turun). Tidak naik atau pun tidak turunnya perputaran persediaan yang dicapai perusahaan membuat laba bersih perusahaan meningkat. Kenaikan laba bersih ini disebabkan karena kenaikan dalam penjualan produknya. Dengan hasil ini menunjukkan bahwa faktor lain lebih memengaruhi laba bersih dibandingkan dengan perputaran persediaan, seperti selisih kurs, penjualan, perputaran piutang, perputaran modal kerja, biaya bunga, beban pajak, dan lainlain.

Hasil pengujian secara simultan pengaruh biaya operasional dan perputaran persediaan terhadap laba bersih secara signifikan berpengaruh terhadap laba bersih. Pengaruh biaya operasional dan perputaran persediaan terhadap laba bersih yaitu sebesar $87 \%$ dengan gap $13 \%$ yang dipengaruhi oleh variabel-variabel lainnya yang tidak diteliti dalam penelitian ini.

Hasil pengujian simultan sangat tinggi dan bersifat positif artinya jika biaya operasional dan perputaran persediaan digabungkan secara simultan maka akan memengaruhi laba bersih, tetapi jika diuji secara parsial perputaran persediaan tidak berpengaruh terhadap laba bersih.

Hal itu dikarenakan jika perputaran persediaan dihitung secara parsial perputaran persediaan mempunyai nilai yang lemah sehingga tidak dapat memengaruhi laba bersih. Tetapi jika secara bersama-sama antara biaya operasional dan perpurtaran persediaan digabungkan perputaran persediaan yang tadinya tidak berpengaruh karena ada dorongan dari biaya operasional maka kesimpulannya simultan atau kekuatan 
secara bersama-sama itu menjadi besar alhasil hasilnya menjadi berpengaruh dengan biaya operasional. Hasil penelitian simultan ini sejalan dengan penelitian Zandra (2016) dan Prasetyo (2017).

\section{Kesimpulan}

Berdasarkan hasil dan pembahasan tersebut secara parsial biaya operasional memengaruhi laba bersih, namun perputaran persediaan tidak berpengaruh terhadap laba bersih. Sedangkan, secara simultan biaya operasional dan perputaran persediaan memengaruhi laba bersih pada PT Ultra Milk Industry \& Trading Company Tbk., dan setiap ada kenaikan biaya operasional ataupun perputaran persediaan maka akan meningkatkan laba bersih. Sebagai rekomendasi untuk mengatasi hal tersebut, maka perusahaan harus menekankan biaya operasionalnya dengan cara mengurangi biaya perbaikan dan pemeliharaan atau mengurangi anggaran dalam perjalanan dinas agar biaya yang dikeluarkan tidak membengkak dan perusahaan harus menambah perolehan pendapatannya baik dari piutang ataupun penjualan dengan cara menjual produk yang dapat diterima dan tidak melanggar peraturan yang ada, sehingga perusahaan berpeluang mendapatkan laba bersih yang lebih besar.

\section{Daftar Pustaka}

Dunia, F. A., \& Wasilah, A. (2012). Akuntansi Biaya. Jakarta: Salemba Empat.

Ghozali, I. (2016). Aplikasi Analisis Multivariete Dengan Program IBM SPSS 23 (Edisi 8). Cetakan ke VIII. Semarang: Badan Penerbit Universitas Diponegoro.

Jusuf, J. (2008). Analisis Kredit Untuk Account Officer, Cetakan kedelapan. Jakarta: Ikrar Mandiri Abadi.
Kasmir, (2014). Analisis Laporan Keuangan, cetakan ke-7. Jakarta: PT Raja Grafindo Persada.

Murhadi, W. (2013). Analisis Laporan keuangan Proyeksi dan Valuasi Saham. Jakarta: Salemba Empat

Prasetyo, P. E. (2017). Pengaruh Biaya Operasional dan Perputaran Persediaan terhadap Laba Bersih. Skripsi. Universitas Komputer Indonesia.

PT Ultrajaya Milk Industry \& Trading Company Tbk. (2017). Laporan Tahunan 2017 (Annual Report). Diakses dari http://www.ultrajaya.co.id/investorrelation/annual-report/ind

Raharjaputra, H. S. (2009). Manajemen Keuangan dan Akutansi untuk Eksekutif Perusahaan. Jakarta: Salemba Empat.

Sartono, A. (2008). Manajemen Keuangan Teori dan Aplikasi. Yogyakarta: BPFE.

Simamora, H. (2013). Pengantar Akuntansi II. Jakarta: Bumi Aksara.

Siregar, S. (2013). Metode Penelitian Kuantitatif (Dilengkapi Perbandingan Perhitungan Manual \& SPSS). Jakarta: Kencana Prenada Media Group.

Sugiyono. (2015). Metode Penelitian Kuantitatif Kualitatif dan $R \& D$. Bandung: Alfabeta.

Syamsuddin, L. (2011). Manajemen Keuangan Perusahaan. Jakarta: PT Grafindo Persada.

Zandra, R. A. P. (2016). Pengaruh Biaya Operasional dan Perputaran Persediaan terhadap Profitabilitas. Aktiva Jurnal Akuntansi dan Investasi, 1(1), 93-107. Diakses dari http://ejournal.unira.ac.id/index.php /jurnal_aktiva/article/view/149 